\title{
Article \\ Efficiency of Visual and Machine Strength Grading of Sawn Timber with Respect to Log Type
}

\author{
Izabela Burawska-Kupniewska * (D), Sławomir Krzosek (D) and Piotr Mańkowski
}

Citation: Burawska-Kupniewska, I.; Krzosek, S.; Mańkowski, P. Efficiency of Visual and Machine Strength Grading of Sawn Timber with Respect to Log Type. Forests 2021, 12, 1467. https://doi.org/10.3390/f12111467

Academic Editor: Michele Brunetti

Received: 6 October 2021

Accepted: 26 October 2021

Published: 27 October 2021

Publisher's Note: MDPI stays neutral with regard to jurisdictional claims in published maps and institutional affiliations.

Copyright: (c) 2021 by the authors. Licensee MDPI, Basel, Switzerland. This article is an open access article distributed under the terms and conditions of the Creative Commons Attribution (CC BY) license (https:// creativecommons.org/licenses/by/ $4.0 /)$.
Institute of Wood Sciences and Furniture, Warsaw University of Life Sciences-SGGW, Nowoursynowska 159, 02-776 Warsaw, Poland; slawomir_krzosek@sggw.edu.pl (S.K.); piotr_mankowski@sggw.edu.pl (P.M.)

* Correspondence: izabela_burawska@sggw.edu.pl

\begin{abstract}
A batch of pine timber sawn from butt, middle and top logs was strength graded with the visual method (classification into grading classes KW-best quality, KS-medium quality, KGinferior quality and Reject) and with the machine strength grading method-performed with the use of a mobile timber grader (classification into $C$ strength classes). We compared the efficiency of grading classes and strength classes, depending on the type of $\log$ from which the material was obtained (butt, middle, top). Next, a strength grading machine was used to measure the modulus of elasticity in bending (MOE) and static bending strength (MOR). The ANOVA confirmed the influence of both the log type (butt, middle, top), the $\mathrm{C}$ strength class, and the visual strength grading class on the values of density (DEN) and MOR. Timber density and MOR decreased from the butt log section to the top log section. The ANOVA confirmed the influence of log type on MOE values, but only to a limited extent.
\end{abstract}

Keywords: stress grading; sawn timber; mechanical properties; MOR; MOE

\section{Introduction}

Wood is a natural, ecological and renewable material with an isotropic structure and a wide range of applications. The variability of mechanical properties, even within the same species - a typical characteristic of wood-hinders its application as a construction material [1,2]. Timber of the same species can have different properties depending on the tree's growth conditions: type of soil, climate and the age of the tree [3-7], and even on the part of the trunk from which the timber was obtained. We can observe changes in timber properties depending on its position within the trunk: butt, middle, or top logs [8-12].

The use of wood in load-bearing applications in civil engineering requires the assessment of the mechanical properties of every single piece of timber used as a load bearing structural element. According to EN 14081-1 [13], wood used in construction has to be strength graded, whether with the use of devices or through visual inspection, in accordance with pertinent national standards. Strength grading machines measure one or several wood properties that can be verified in a non-destructive way, and whose correlation with the wood's bending strength is known. Usually, these are the static or dynamic modulus of elasticity and the density of the timber under assessment. As a result of machine strength grading, coniferous timber is classified into $C$ strength classes, whose characteristics have been specified in EN 338 [14]. Modern scanners and grading machines make use of multiple methods (X-ray photographs, photographs of surfaces, laser scans using the tracheid effect) to acquire in-depth data, which-combined with the mechanical or dynamic stiffness associated with density-provide high-precision strength grading [15-20].

Visual strength grading of construction lumber consists of examining every piece of timber carefully and classifying it into the appropriate grading class on the basis of the visible defects of wood structure, shape and processing. Most EU member states have their own national standards regulating the strength grading process with the visual method, 
which should be in line with the harmonised EN 14081 standard [13]. Visual strength grading classifies timber into sorting or grading classes.

In many European countries, comparative research has been carried out on the mechanical properties of timber graded with the use of a strength grading device or with the visual method [8,21-29]. It has been consistently noted that machine strength grading results in a much higher efficiency, with timber classified into higher grades and far fewer rejected pieces, in comparison with the results of strength grading of the same batch of timber with the use of the visual method.

A study performed by Gaunt et al. (1999) revealed that visual strength grading can result in a high percentage of strength grading errors [30]. The efficiency of strength grading can be further improved by developing a model that takes into account a series of input data related to the tree and the timber obtained from it: site (fertility, etc.), silviculture, (thinning, stocking, branch size, etc.), age of harvest, genetics (wood density, growth rate), $\log$ form and position in the tree, distribution of branches, sawing pattern, piece position in the log, etc. [31]. The development of an integrated model that takes into account all of the above input data cannot be achieved without allocating significant financial and material resources. In addition, we know how much these variables influence the results of machine strength grading $[32,33]$. Nowadays, the wood industry has a very strong position in the market, based on the strategy of producing strength-graded construction timber with the best possible use of natural forest resources [34,35].

The study presented here is aimed at developing and complementing the existing state of knowledge within the scope of influences on the efficiency of machine or visual strength grading, taking into account the type of log from which the timber under assessment was obtained (butt, middle, top). An additional goal consisted of evaluating the strength properties of structural timber produced in Poland by means of visual grading, as well as tests of mechanical properties, in order to determine the distribution of specimens according to strength classes. These research results may contribute to a more rational selection of round timber in terms of its anticipated structural applications.

\section{Experimental Tests}

\subsection{Materials}

The research materials consisted of a batch of Scots pine timber (Pinus sylvestris L.) composed of 510 pieces with the nominal cross-section dimensions of $40 \times 138 \mathrm{~mm}$, and a length of $3.5 \mathrm{~m}$. The timber was obtained from a middle-sized sawmill in Poland. The technical quality of the stand was 2, which corresponds to stands that are usually well adjusted to the habitat, with good development dynamics, healthy, straight, and where well cleaned tree-length trunks are expected to provide good quality sawn timber. The timber was acquired from raw wood that was approximately 120 years old. Roundwood came from trees growing in moist-mixed forest. The timber was obtained from three types of logs: butt (170 pieces), middle (170 pieces), and top (170 pieces; Figure 1). After logging, the timber was dried in industrial conditions in a chamber drier, up to the humidity of ca. $12 \%$, and sawn. 


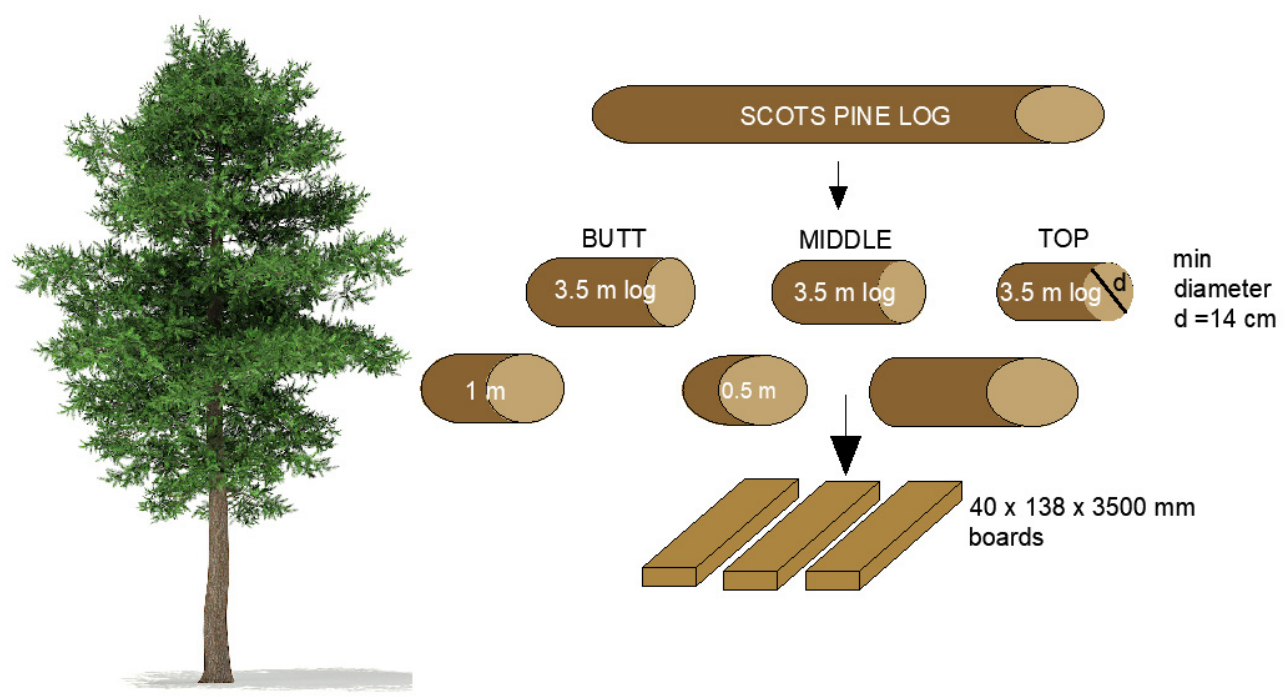

Figure 1. Diagram presenting divisions of the trunk into logs and boards.

\subsection{Methods}

A batch of pine timber (510 pieces) sawn from butt, middle and top logs was strength graded with the visual method [36]. Later, the same batch of timber was strength graded with a grading device and classified into the $C$ strength classes [14] with the use of a mobile timber grader (MTG; Brookhuis Applied Technologies, Enschede, The Netherlands).

The next stage of research consisted of measuring the static modulus of elasticity (MOE) and static bending strength-modulus of rupture (MOR) - in line with [37], with the use of a universal resistance machine TIRA Test 2300 (TIRA GmbH, Schalkau, Germany). The tests were performed with displacement control (load head speed $3 \mathrm{~mm} / \mathrm{min}$ ) according to the diagram presented in Figure 2. After the test, a sample of wood free from defects and covering the entire cross-section was taken from the rupture area of each board to measure the timber density (DEN) and moisture content using the oven dry method.

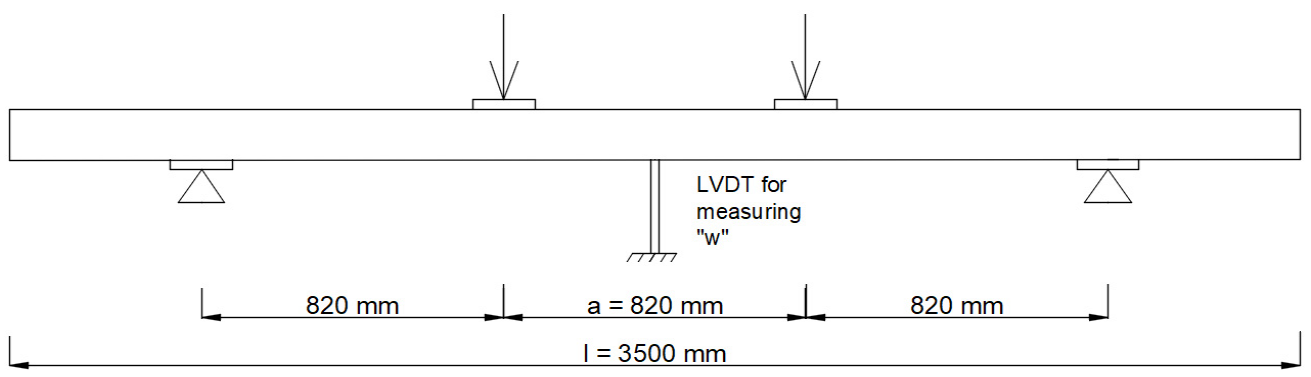

Figure 2. Static diagram of a four-point bending test to determine MOE and MOR, where LVDT-linear variable differential transformer, $\mathrm{w}$-deflection.

Statistical analysis of test results was carried out in Statistica v.13.3 software (StatSoft, Inc., Tulsa, OK, USA). The obtained values for the physical and mechanical properties were analysed as average values, taking into account the standard deviation. Two-factor variance analysis (ANOVA) was performed for the physical and mechanical properties of Scots pine sawn timber (DEN, MOE, MOR)—-depending on the log type (B-butt, Mmiddle, T-top) and sawn timber quality-obtained from machine strength grading and expressed by a C class [14], and with grading classes determined on the basis of visual strength grading (KW, KS, KG, Reject) [36]. All the tests were carried out for a significance level of $p<0.05$. 


\section{Results and Discussion}

Table 1 presents the efficiency of timber grading depending on the method-visual or machine strength grading.

Table 1. Number of timber pieces classified in each class according to $[14,36]$.

\begin{tabular}{|c|c|c|c|c|c|c|}
\hline Strength Class & Log Type & All & KW & KS & KG & $\mathbf{R}$ \\
\hline \multirow{3}{*}{$\begin{array}{c}\text { All } \\
(510)\end{array}$} & B & 170 & 32 & 29 & 54 & 55 \\
\hline & $\mathrm{M}$ & 170 & 13 & 15 & 66 & 76 \\
\hline & $\mathrm{T}$ & 170 & 7 & 9 & 67 & 87 \\
\hline \multirow{3}{*}{$\begin{array}{l}\text { C40 } \\
(29)\end{array}$} & $\mathrm{B}$ & 23 & 6 & 5 & 7 & 5 \\
\hline & M & 6 & 1 & 1 & 2 & 2 \\
\hline & $\mathrm{T}$ & 0 & 0 & 0 & 0 & 0 \\
\hline \multirow{3}{*}{$\begin{array}{l}\text { C35 } \\
(91)\end{array}$} & $\mathrm{B}$ & 60 & 15 & 15 & 18 & 12 \\
\hline & M & 28 & 2 & 8 & 13 & 5 \\
\hline & $\mathrm{T}$ & 3 & 0 & 1 & 0 & 2 \\
\hline \multirow{3}{*}{$\begin{array}{l}\text { C30 } \\
(130)\end{array}$} & $\mathrm{B}$ & 46 & 11 & 7 & 17 & 11 \\
\hline & M & 55 & 6 & 2 & 27 & 20 \\
\hline & $\mathrm{T}$ & 29 & 3 & 6 & 10 & 10 \\
\hline \multirow{3}{*}{$\begin{array}{l}\text { C24 } \\
(200)\end{array}$} & $\mathrm{B}$ & 23 & 0 & 1 & 10 & 12 \\
\hline & M & 69 & 4 & 3 & 23 & 39 \\
\hline & $\mathrm{T}$ & 108 & 4 & 2 & 46 & 56 \\
\hline \multirow{3}{*}{$\begin{array}{l}\text { C18 } \\
(43)\end{array}$} & B & 9 & 0 & 0 & 1 & 8 \\
\hline & M & 10 & 0 & 1 & 1 & 8 \\
\hline & $\mathrm{T}$ & 24 & 0 & 0 & 7 & 17 \\
\hline \multirow{3}{*}{$\begin{array}{l}\text { Reject } \\
(9)\end{array}$} & $\mathrm{B}$ & 1 & 0 & 0 & 0 & 1 \\
\hline & M & 2 & 0 & 0 & 0 & 2 \\
\hline & $\mathrm{T}$ & 6 & 0 & 0 & 4 & 2 \\
\hline \multirow{3}{*}{$\begin{array}{c}\text { Error } \\
(8)\end{array}$} & B & 8 & 0 & 1 & 1 & 6 \\
\hline & $\mathrm{M}$ & 0 & 0 & 0 & 0 & 0 \\
\hline & $\mathrm{T}$ & 0 & 0 & 0 & 0 & 0 \\
\hline
\end{tabular}

An analysis of the results of the visual strength grading in view of the type of log of origin suggests that top logs produce a very low efficiency of construction timber in higher classes (KW-4.1\% and KS-5.3\%), while the efficiency of the lower KG class amounts to $39.4 \%$, and as much as $51 \%$ of timber pieces from top logs are rejected. This is a direct result of the large, open knots present in the top parts of the trees, which remain as marks of the branches that used to create the tree crown before it was logged. A significantly better result was obtained for the remaining log types: middle and butt. A comparison of the number of timber pieces from butt and middle logs in KW and KS classes shows a lack of influence of the log of origin on the results of visual strength grading. A clear influence of log origin can be noted in the cases of KG and Rejects. Both KG and Rejects contained fewer butt log timber pieces than timber pieces from middle logs. The results that have been obtained here confirm that the best quality timber can be sourced from butt logs (these logs usually contain small, overgrown knots near the pith, and large surfaces of the cross section are free from defects), while the worst quality timber for this kind of application is obtained from top logs (usually large, open knots sticking out towards the sides and edges of the sawn timber).

The timber batch under research was characterised by its low quality (pieces classified in the Reject and KG categories jointly amounted to $67.6 \%$ ), compared to other timber of similar origins (different forestry regions in Poland). Research carried out in previous years provided a more favourable share of grading classes with concern to grading efficiency, and in the case of a particular batch, the shares of classes were as follows: KW $39.5 \%, \mathrm{KS}-14.8 \%$, KG-28.6\%, Reject-17.1\% [38]. A study of timber from five different forestry regions in Poland revealed that one particular region—the Silesian forestry region-provided a 
higher share of the highest quality timber, $\mathrm{KW}$, by $24.6 \%$ more than the average share of the remaining forestry regions [29].

As a result of machine strength grading of the same batch of pine timber (510 pieces), only nine pieces were rejected (low density and dynamic modulus of elasticity values) and eight pieces could not be classified (error on the MTG display, probably due to roughly cut board ends and a failure to indicate the MOE dyn, and the $\mathrm{C}$ grade correlated with it). When calculating them together as timber not suitable for construction applications, they summed up to 17 pieces, which equals $3.3 \%$ of the entire timber batch. On the basis of the results of the strength grading done with both methods, it can be concluded that visual strength grading is much more restrictive, and that timber sorted in this manner has a large safety margin.

On the basis of previous research on Polish-grown pine timber [29], it can be assumed that the visual $\mathrm{KW}$ class corresponds to the C30 class, $\mathrm{KS}$ corresponds to C24, and KG corresponds to $\mathrm{C} 18$. Therefore, visual strength grading resulted in 52 pieces $(10.2 \%$ of the entire batch) classified as $\mathrm{C} 30$, while the machine strength grading method resulted in 250 pieces ( $49 \%$ of the entire batch) classified as $\mathrm{C} 30$ or better $(\mathrm{C} 30+\mathrm{C} 35+\mathrm{C} 40)$. The visual method resulted in 53 pieces classified as C24 (10.4\% of the entire batch), while the machine strength grading method resulted in 200 pieces classified as C24 (39.2\% of the entire batch). As to the C18 class, there were 187 pieces (36.7\% of the batch) classified by the visual strength grading method, and 43 pieces ( $8.4 \%$ of the batch) classified as C18 with the machine method. Similar correlations-higher efficiency of better grading classes achieved with the machine strength grading method-were also observed by other researchers [23,29].

When analysing the influence of the type of log from which the timber was sawn on the strength grading results, it was observed that the highest efficiency of higher strength classes (C40 and C35) was achieved for butt logs. In the case of the C30 class, the highest efficiency was achieved for middle logs with the machine strength grading method (55 pieces, which amounts to $42.3 \%$ of the timber pieces in this class) and the lowest efficiency for timber from top logs (29 pieces, $22.3 \%$ of timber pieces in this class). An analysis of these results suggests that butt logs are the best source of high-class timber for construction applications, independently of the strength grading method. When comparing the two strength grading methods, the machine strength grading method always has a higher efficiency for higher classes, independently of the place of origin of the logs.

Other studies of Scots pine sawn timber produced the following efficiency for each C class: C40-0.5\%, C35-5.8\%, C30-16.7\%, C24-36.8\%, C18-22.7\%, Reject-17.5\% [29], and $\mathrm{C} 40-5.7 \%, \mathrm{C} 35-17.8 \%, \mathrm{C} 30-25.5 \%, \mathrm{C} 24-39.2 \%, \mathrm{C} 18-8.4 \%$, Reject-1.8\% [39].

Figures 3-5 present the results of studies of timber, taking into account the type of $\log$ of origin (butt, middle, top) and the quality of timber-classified both as a $C$ strength class and a grading class (KW, KS, KG, Reject). There were a few pieces that could not be machine strength graded, as the MTG device displayed the "Error" message. These pieces were not taken into account in further analysis.
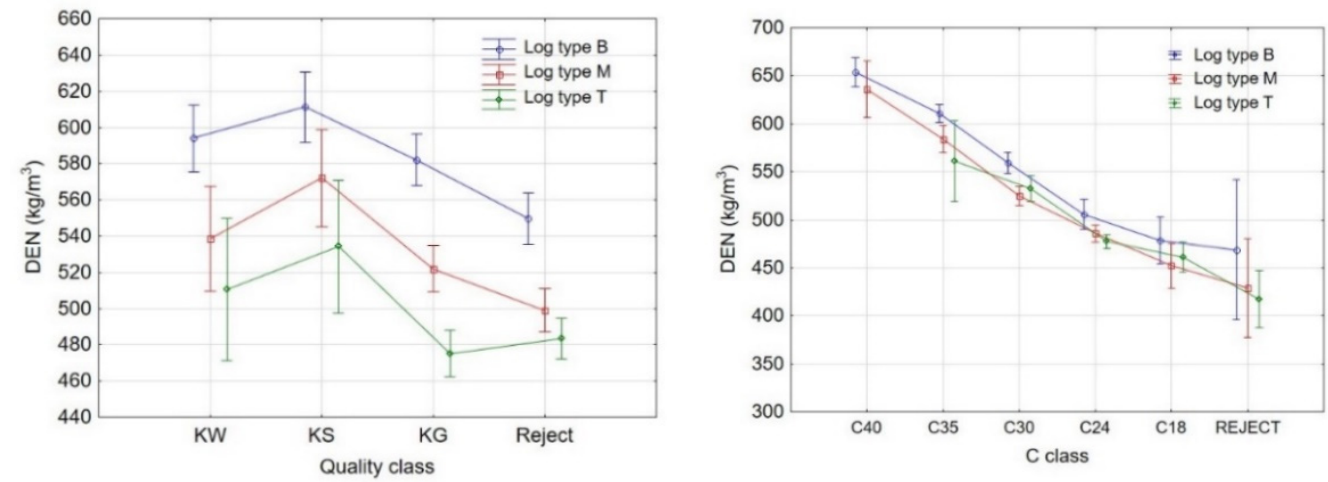

Figure 3. Density distribution in relation to timber quality. 

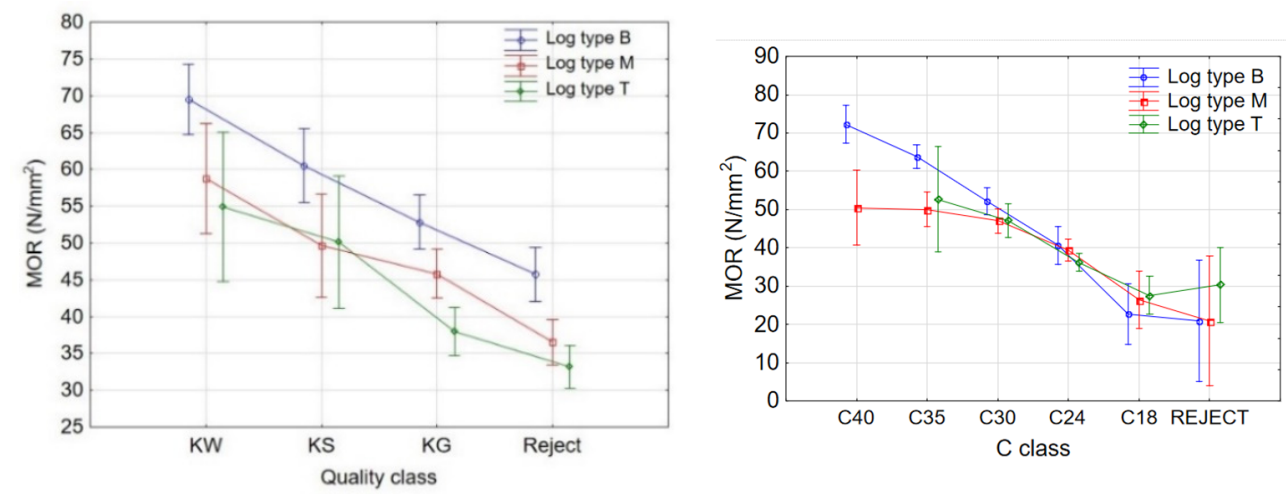

Figure 4. MOR distribution in relation to timber quality.
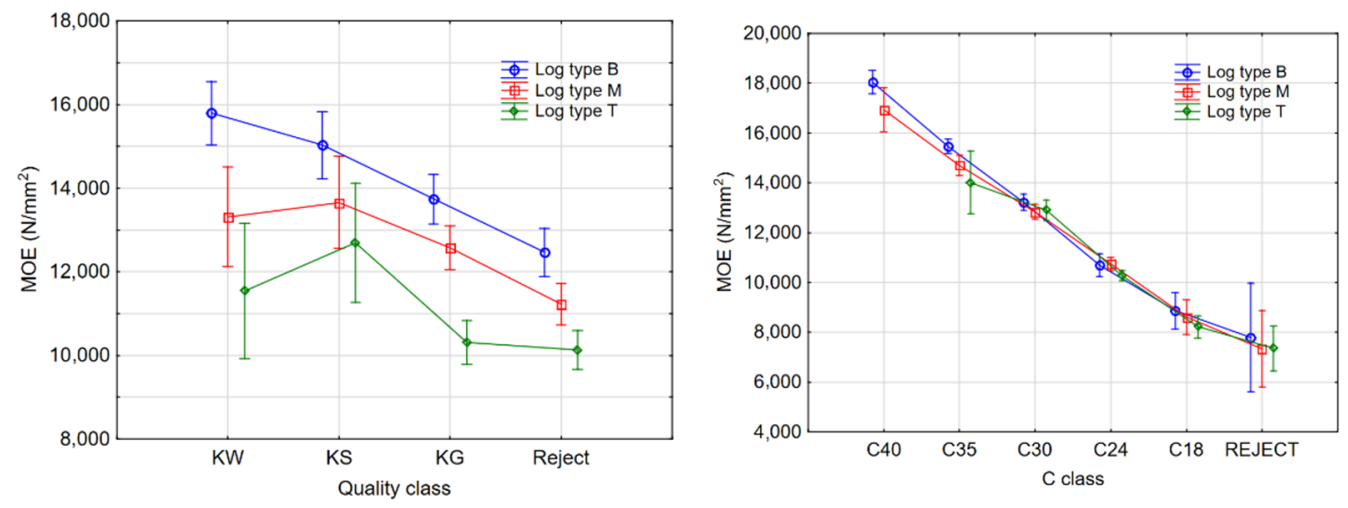

Figure 5. MOE distribution in relation to timber quality.

When analysing the results of the laboratory tests of the timber under research (Figure 3), the highest average density values were observed for timber from butt logs, and the lowest for timber from top logs. Within each class from C18 to C40, the highest density value was measured for timber from butt logs. The ANOVA (Table 2) confirmed the influence of the log type (butt, middle, top), the strength class $C$, and the visual strength grading class on the values for density. Similar correlations in relation to Scots pine timber were also found by Mirski et al.; the highest density, at the level of $610 \mathrm{~kg} / \mathrm{m}^{3}$, was measured for timber from butt logs, while the lowest $-548 \mathrm{~kg} / \mathrm{m}^{3}$ - was measured for timber from top logs [40]. Similar findings were reported by Jelonek et al. [41], who observed the highest value of density in the case of the Scots pine obtained from the trunk at breast height (equivalent of butt logs), and the lowest for timber from the height of the crown (equivalent of top logs). This correlation was also reported by an Estonian study performed by Pikk and Kask [42], a Swedish study [43] and a Finnish study [44]. The dependence of density on the type of $\log$ from which the tested sawn timber came is directly related to the material characteristics. Timber obtained from butt logs is typically characterized by a higher proportion of heartwood compared to sapwood. Heartwood formation involves a number of physiological, anatomical, cellular, and chemical changes [45]. Heartwood has a tighter tissue of a higher density and more favorable strength parameters compared to sapwood, which translates into the final quality and properties of the material.

On the basis of Figure 4, it can be observed that the MOR decreased from the butt $\log$ section to the top log section. The MOR values of timber from the grading classes determined by visual strength grading, independently of log type, were lower for lower quality pieces. Moreover, the ANOVA (Table 2) showed a direct relationship between the MOR value and the type of log, as well as the $C$ strength classes-both as independent influences of the individual factors, and in case of both factors acting at the same time. On the basis of research carried out on Norwegian spruce timber, it was confirmed that a higher vertical position in the tree leads to a decrease in MOR values [46]. The reduction of 
MOR values can reach as much as $20 \%$ in the case of differences between stem height levels of $35 \%$ and $65 \%$ [47]. In the case of spruce wood, there is a similar correlation between the type of log and the timber's bending strength. Wood from butt logs had an average MOR of $56 \mathrm{MPa}$, while the MOR of timber from top logs was $45 \%$ lower [8].

Table 2. Values of ANOVA for density, MOE and MOR, depending on the type of log, log quality, and the assigned strength class.

\begin{tabular}{|c|c|c|c|c|c|c|}
\hline Feature & Factor & SS & DF & MS & $\mathbf{F}$ & $p$ \\
\hline \multirow{8}{*}{ DEN } & Log type (1) & 337,845 & 2 & 168,922 & 60.51 & $0.000000 *$ \\
\hline & Quality class (2) & 151,089 & 3 & 50,363 & 18.04 & 0.000000 * \\
\hline & $1 * 2$ & 33,076 & 6 & 5513 & 1.97 & $0.067638^{\mathrm{NS}}$ \\
\hline & Error & $1,379,002$ & 494 & 2792 & - & - \\
\hline & Log type (1) & $13,193.5$ & 1 & $13,193.49$ & 9.58785 & 0.002073 * \\
\hline & $\mathrm{C}$ class $(2)$ & $386,695.5$ & 4 & $96,673.86$ & 70.25390 & 0.000000 * \\
\hline & $1 * 2$ & 7659.6 & 9 & 851.07 & 0.61848 & $0.781629^{\mathrm{NS}}$ \\
\hline & Error & $661,886.8$ & 481 & 1376.06 & & \\
\hline \multirow{8}{*}{ MOE } & Log type (1) & $4.297901 \times 10^{8}$ & 2 & $2.148950 \times 10^{8}$ & 45.360 & $0.000000 *$ \\
\hline & Quality class (2) & $3.390675 \times 10^{8}$ & 3 & $1.130225 \times 10^{8}$ & 23.857 & 0.000000 * \\
\hline & $1 * 2$ & $5.157203 \times 10^{7}$ & 6 & $8.595338 \times 10^{6}$ & 1.814 & $0.094395^{\mathrm{NS}}$ \\
\hline & Error & $2.340350 \times 10^{9}$ & 494 & $4.737550 \times 10^{6}$ & - & - \\
\hline & Log type (1) & $4.199435 \times 10^{6}$ & 1 & $4,199,435$ & 3.4023 & $0.065719 \mathrm{NS}$ \\
\hline & C class $(2)$ & $1.017103 \times 10^{9}$ & 4 & $254,275,730$ & 206.0095 & $0.000000 *$ \\
\hline & $1 * 2$ & $1.263513 \times 10^{7}$ & 9 & $1,403,904$ & 1.1374 & $0.334314^{\mathrm{NS}}$ \\
\hline & Error & $5.949283 \times 10^{8}$ & 482 & $1,234,291$ & - & - \\
\hline \multirow{8}{*}{ MOR } & Log type (1) & 9474.9 & 2 & 4737.4 & 25.158 & $0.000000 *$ \\
\hline & Quality class (2) & $20,955.2$ & 3 & 6985.1 & 37.095 & $0.000000 *$ \\
\hline & $1 * 2$ & 601.8 & 6 & 100.3 & 0.533 & $0.783591^{\mathrm{NS}}$ \\
\hline & Error & $93,587.0$ & 497 & 188.3 & - & - \\
\hline & Log type (1) & 710.30 & 1 & 710.298 & 4.80597 & 0.028837 * \\
\hline & C class $(2)$ & $22,555.93$ & 4 & 5638.982 & 38.15409 & $0.000000 *$ \\
\hline & $1 * 2$ & 4015.32 & 9 & 446.147 & 3.01869 & 0.001614 * \\
\hline & Error & $71,532.77$ & 484 & 147.795 & - & - \\
\hline
\end{tabular}

SS—sum of squares; DF—degrees of freedom; MS—-mean sum of squares; F-Fisher's F-test; $p$-significance level; * - significant at the 0.05 level; NS-not significant.

In the case of MOE (Figure 5), the highest average values were obtained for timber made of butt logs, and the lowest for timber made of top logs. The ANOVA (Table 2) confirmed the influence of log type on MOE values, but only to a limited extent. In the case of wood strength graded by the visual method, there was a significant influence of the log type on the MOE of timber, but in the case of wood sorted by machine strength grading, such an influence was not observed $(p<0.05)$. Nonetheless, the literature contains many research results concerning the influence of log types on MOE. For example, a study by Mirski et al. [40] revealed that timber originating from butt logs had average MOE values almost $27 \%$ higher than timber from top logs. The same trends were observed for loblolly pine in the United States by Antony et al. [48]. 


\section{Conclusions}

As a result of machine strength grading, far fewer timber pieces are rejected than with visual strength grading (machine assisted method: 3.3\% pieces rejected, visual strength grading: $42.7 \%$ timber pieces rejected).

The machine strength grading method resulted in a higher efficiency of higher strength classes compared with the visual strength grading method, which contributes to rational wood management and production of construction sawn timber.

In the case of visual strength grading, we confirmed a statistically significant influence of the type of log on the average density, MOE and MOR values of the timber under research. In the case of the machine strength grading method, a statistically significant correlation was observed only for the average values of density and the MOR.

In the case of both strength grading methods (visual and machine-assisted), there was a statistically significant influence of timber quality (the grading class/strength class) on the average values of density, MOE and MOR.

Author Contributions: Conceptualization, I.B.-K. and S.K.; methodology, I.B.-K., P.M. and S.K.; software, I.B.-K. and P.M.; validation, I.B.-K. and S.K.; formal analysis, I.B.-K. and S.K.; investigation, I.B.-K., P.M. and S.K.; resources, I.B.-K., P.M. and S.K.; data curation, I.B.-K., P.M. and S.K.; writingoriginal draft preparation, I.B.-K., P.M. and S.K.; writing—review and editing, I.B.-K.; visualization, I.B.-K.; supervision, S.K.; project administration, I.B.-K. and S.K.; funding acquisition, S.K. All authors have read and agreed to the published version of the manuscript.

Funding: The authors are grateful for the support of the National Centre for Research and Development, Poland, under "Environment, agriculture and forestry"-BIOSTRATEG strategic R\&D program, Agreement No. BIOSTRATEG3/344303/14/NCBR/2018.

Institutional Review Board Statement: Not applicable.

Informed Consent Statement: Not applicable.

Data Availability Statement: Not applicable.

Acknowledgments: The authors would like to thank Marek Grześkiewicz (Institute of Wood Sciences and Furniture, Warsaw University of Life Sciences, SGGW) for his help with the machine stress grading of timber using MTG device.

Conflicts of Interest: The authors declare no conflict of interest.

\section{References}

1. Obede, B.F.; Silva, D.A.L.; Rocco, F.A.; Chahud, E.; Varanda, L.D. Influence of wood moisture content on modulus of elasticity on tension parallel to the grain of Brazilian species. Eur. Int. J. Sci. Technol. 2012, 1, 11-22.

2. Christoforo, A.L.; Panzera, T.H.; Silva, L.J.; Araújo, V.A.; Silva, D.A.L.; Rocco, F.A. Evaluation of the modulus of elasticity in damaged wooden beams. Int. J. Mater. Eng. 2020, 5, 92-97. [CrossRef]

3. Zobel, B.J.P. Wood Variation: Its Causes and Control; Springer: Berlin, Germany, 1989.

4. Savidge, R.A. Tree growth and wood quality. In Wood Quality and Its Biological Basis; Barnett, J.R., Jeronimidis, G., Eds.; Blackwell Publishing \& CRC Press: Oxford, UK, 2003; pp. 1-29.

5. Mederski, P.S.; Bembenek, M.; Karaszewski, Z.; Giefing, D.F.; Sulima-Olejniczak, E.; Rosińska, M.; Lacka, A. Density and mechanical properties of Scots pine (Pinus sylvestris L.) wood from a seedling seed orchard. Drewno. Prace Naukowe. Doniesienia. Komunikaty. 2015, 58, 117-124. [CrossRef]

6. Rocha, M.F.V.; Veiga, T.R.L.A.; Soares, B.C.D.; Araújo, A.C.C.D.; Carvalho, A.M.M.; Hein, P.R.G. Do the growing conditions of trees influence the wood properties? Floresta E Ambiente 2019, 26. [CrossRef]

7. Zeidler, A.; Boruvka, V.; Schönfelder, O. Comparison of Wood Quality of Douglas Fir and Spruce from Afforested Agricultural Land and Permanent Forest Land in the Czech Republic. Forests 2018, 9, 13. [CrossRef]

8. Glos, P.; Henrici, D.; Lederer, B. Verbesserung der Wettbewerbsfähigkeit der Sägeindustrie durch Erhöhung der Schnittholzqualität [Improvement of Competitiveness Sawmill Industry via Enhancement of Timber Quality] (Report No. 96507); Wood Research Munich: Munich, Germany, 1999.

9. Teischinger, A.; Patzelt, M. XXL-Wood. Materialkenngrößen als Grundlage für innovative Verarbeitungstechnologien und Produkte zur wirtschaftlichen nachhaltigen Nutzung der Österreichischen Nadelstarkholzreserven. In Berichte aus Energie-und Umweltforschung 27/2006 (Material Properties as the Basis for Innovative Products and Technologies for the Rational Use of Austrian Reserves of Large-Diameter Softwoods); Universität für Bodenkultur Wien: Wien, Austria, 2006. 
10. Kraler, A.; Maderebner, R. Gebirgsholz-Wald ohne Grenzen; deutliche Verbesserung des Marktwertes Süd-Ost-E Nordtiroler Gebirgshölzer und ausgewählter Holznischenprodukte [Wood from the Mountains_Forest without Bordezrs; Marked Improvement in the Market Value of Wood from South, East and North Tyrol and Selected Niche Wood Products]; Institut für Konstruktion und Materialwissenschaften Arbeitsbereich Holzbau, Leopold Franzens Universität Innsbruck: Innsbruck, Austria, 2012.

11. Johansson, M.; Kliger, R. Variability in strength and stiffness of structural Norway spruce timber: Influence of raw material parameters. In Proceedings of the World Conference on Timber Engineering; Barrett, J.D., Ed.; WCTE: Whistler, BC, Canada, $2000 ;$ p. 9.

12. Haartveit, E.Y.; Flæte, P.O. Mechanical properties of Norway spruce lumber from monocultures and mixed stands-Modelling bending stiffness and strength using stand and tree characteristics. In Proceedings from the Fourth Workshop "Connection between Forest Resources and Wood Quality: Modelling Approaches and Simulation Software; Nepveu, G., Ed.; IUFRO: Vienna, Austria, 2002; pp. 346-355.

13. EN 14081-1. Timber Structures—Strength Graded Structural Timber with Rectangular Cross Section-Part 1: General Requirements; European Committee for Standarization (CEN): Brussels, Belgium, 2016.

14. EN 338. Timber Structures_Strength Classes; European Committee for Standarization (CEN): Brussels, Belgium, 2016.

15. Denzler, J.K.; Diebold, R.; Glos, P. Machine strength grading-commercially used grading machines-current developments. In Proceedings of the 14th International Symposium on Nondestructive Testing of Wood, Eberswalde, Germany, 2-4 May 2005; Friedrich-Wilhelm Broker; Fachhochschule Eberswalde; Shaker: Aachen, Germany, 2005; pp. 11-16.

16. Bacher, M. Comparison of different machine strength grading principles. In Proceedings of the COST E53 Conference, Delft, The Netherlands, 29-30 October 2008; Gard, W.F., van de Kuilen, J.W.G., Eds.; Delft University of Technology: Delft, The Netherlands, 2008; pp. 183-193.

17. Ridley-Ellis, D.; Stapel, P.; Baño, V. Strength grading of sawn timber in Europe: An explanation for engineers and researchers. Eur. J. Wood Wood Prod. 2016, 74, 291-306. [CrossRef]

18. Giudiceandrea, F. Stress grading lumber by a combination of vibration stress waves and X-ray Scanning. In Proceedings of the 11th International Conference on Scanning Technology and Process Optimization in the Wood Industry (Scan Tech 2005), Las Vegas, NV, USA, 24-26 July 2005; Szymani, R., Ed.; Wood Machining Institute: Berkeley, CA, USA, 2005; pp. 99-108.

19. Krzosek, S.; Grześkiewicz, M.; Bacher, M. Mechanical properties of Polish-grown Pinus silvestris L. structural sawn timber. In Proceedings of the COST E53 Conference Proceedings, Delft, The Netherlands, 29-30 October 2008; pp. 253-260.

20. Krzosek, S.; Bacher, M. Aktueller Stand der maschinellen Festigkeitssortierung von Schnittholz in Polen und in Europa. Ann. Wars. Univ. Life Sci.-SGGW. For. Wood Technol. 2011, 74, 254-259.

21. Glos, P.; Burger, N. Maschinelle Sortierung von Frisch eingeschnittenen Schnittholz. Holz Roh Werkst. 1998, 56, 319-329. [CrossRef]

22. Glos, P.; Becker, G.; Diebold, R.; Pelz, S. Einstufung von Douglasie in die europäischen festigkeitsklassen [classification of douglas fir into the European strength classes]. In Report No. 97501; Wood Research Munich: Munich, Germany, 1998.

23. Glos, P.; Schleifer, A. Maschinelle Festigkeitssortierung von Kiefernschnittholz. Holzforschung München. Abschlussbericht Nr. 01515. München 2002 (Mechanical Strength Grading of Pine Lumber. Wood Research Munich. Final Report Nr. 01515. Technical University Munich); Technical University Munich: Munchen, Germany, 2002.

24. Hanhijärvi, A.; Ranta-Maunus, A.; Turk, G. Potential of Strength Grading of Timber with Combined Measurement Techniques (Report of the Combigrade-Project Phase 1); VTT Publications 568: Espoo, Finland, 2005.

25. Hanhijärvi, A.; Ranta-Maunus, A. Development of strength grading of timber using combined measurement techniques. In Report of the Combigrade_-Project Phase 2; VTT Technical Research Centre of Finland: Espoo, Finland, 2008.

26. Nocetti, M.; Bacher, M.; Brunetti, M.; Crivellaro, A.; van de Kuilen, J.-W. Machine grading of Italian structural timber: Preliminary results on different wood species. In Proceedings of the World Conference on Timber Engineering, Trento, Italy, 20-24 June 2010; Ceccotti, A., van de Kuilen, J.W., Eds.; WCTE: Riva Del Garda, Italy, 2010.

27. Diebold, R.; Schleifer, A.; Glos, P. Machine grading of structural sawn timber from various softwood and hardwood species. In Proceedings of the 12th International Symposium on Nondestructive Testing of Wood, Sopron, Hungary, 13-15 September 2000; University of Wester Hungary: Sopron, Hungary, 2000; pp. 139-146.

28. Krzosek, S.; Grzeskiewicz, M. Strength grading Polish grown Pinus sylvestris L. structural timber using Timber Grader MTG and visual method. Ann. Wars. Univ. Life Sci.-SGGW For. Wood Technol. 2008, 66, 26-31.

29. Krzosek, S. Wytrzymałościowe Sortowanie Polskiej Sosnowej Tarcicy Konstrukcyjnej Rożnymi Metodami [Strength Grading of Polish Pine Structural Sawn Timber]; Wydawnictwo SGGW: Warsaw, Poland, 2009.

30. Gaunt, D.J.; Roper, J.; Davy, B. Performance Grading of New Zeland Pine and the Development of the "E-Grader"; Presentation to NZ Timber Industry Federation: Brisbane, Australia, 1999.

31. Gaunt, D. A revolution in structural timber grading. In Proceedings of the WCTE Conference, Timber Engineering Challenges and Solutions, Auckland, New Zeland, 15-19 July 2012; Editor Curran Associates: Red Hook, NY, USA, 2012 ; pp. $276-283$.

32. Bucur, V. Nondestructive Characterization and Imaging of Wood; Springer: Berlin/Heidelberg, Germany, 2003; 214p.

33. Mišeikyte, S.; Baltrušaitis, A.; Kudakas, L. Strength and stiffness properties of the Lithuanian grown Scots pine (Pinus sylvestris): Comparison of various testing methods. In Proceedings of the 4th meeting of the Nordic Baltic Network in Wood Material Science and Engineering (WSE), Riga, Latvia, 13-14 November 2008; Latvian State Institute of Wood Chemistry: Riga, Latvia, 2008; pp. 101-107.

34. Luttenberger, L.R. Waste management challenges in transition to circular economy. Case Croatia. J. Clean. Prod. 2020, 256, 120495. [CrossRef] 
35. International Advisory Council on Global Bioeconomy. Expending the sustainable bioeconomy-Vision and way forward. In Communique of the Global Bioeconomy Summit; International Advisory Council on Global Bioeconomy: Berlin, Germany, 2020.

36. PN-D-94021. Tarcica Konstrukcyjna Iglasta Sortowana Metodami Wytrzymałościowymi (Coniferous Construction Timber Sorted by Strength Methods); Polish Committee for Standardization (PKN): Warsaw, Poland, 2013.

37. EN $408+$ A1. Timber Structures-Structural Timber and Glued Laminated Timber. Determination of Some Physical and Mechanical Properties; European Committee for Standardization (CEN): Brussels, Belgium, 2012.

38. Burawska-Kupniewska, I.; Krzosek, S.; Mańkowski, P.; Grześkiewicz, M. Quality and bending properties of Scots Pine (Pinus Sylvestris L.) sawn timber. Forests 2020, 11, 1200. [CrossRef]

39. Burawska-Kupniewska, I.; Mańkowski, P.; Krzosek, S. Mechanical properties of machine stress graded sawn timber depending on the log type. Forests 2021, 12, 532. [CrossRef]

40. Mirski, R.; Dziurka, D.; Chuda-Kowalska, M.; Wieruszewski, M.; Kawalerczyk, J.; Trociński, A. The usefulness of pine timber (Pinus sylvestris L.) for the production of structural elements. Part I: Evaluation of the quality of the pine timber in the bending test. Materials 2020, 13, 3957. [CrossRef]

41. Jelonek, T.; Pazdrowski, W.; Tomczak, A.; Grzywiński, W. Biomechanical stability of pines growing on former farmland in northern Poland. Wood Res. 2012, 57, 31-44.

42. Pikk, J.; Kask, R. Mechanical properties of juvenile wood of Scots pine (Pinus sylvestris L.) on Myrtillus forest site type. Balt. For. 2004, 10, 72-78.

43. Björklund, L.; Walfridsson, E. Tallvedens egenskaper i Sverige-Torr-rådensitet, kärnvedhalt, fuktighet och barkhalt. [Properties of scots pine wood in Sweden: Basic density, heartwood, moisture and bark content]. In Rapport Nr. 234; Swedish University of Agriculture Sciences, Department of Forest Products: Uppsala, Sweden, 1993; p. 67.

44. Repola, J. Models for vertical wood density of Scots pine, Norway spruce and birch stems, and their application to determine average wood density. Silva Fenn. 2006, 40, 673-685. [CrossRef]

45. Hillis, W.E. The Formation of Heartwood and Its Extractives. In Phytochemicals in Human Health Protection, Nutrition, and Plant Defense. Recent Advances in Phytochemistry. Proceedings of the Phytochemical Society of North America; Springer: Boston, MA, USA, 1999; Volume 33, Chapter 9; pp. 215-253.

46. Šilinskas, B.; Varnagirytė-Kabašinskienè, I.; Aleinikovas, M.; Beniušienè, L.; Aleinikovienè, J.; Škèma, M. Scots pine and norway spruce wood properties at sites with different stand densities. Forests 2020, 11, 587. [CrossRef]

47. Machado, J.S.; Cruz, H.P. Within stem variation of Maritime pine timber mechanical properties. Holz Roh Werkst. 2005, 63, 154-159. [CrossRef]

48. Antony, F.; Jordan, L.; Schimleck, L.R.; Clark, A.; Souter, R.A.; Daniels, R.F. Regional variation in wood modulus of elasticity (stiffness) and modulus of rupture (strength) of planted loblolly pine in the United States. Can. J. For. Res. 2011, 41, 1522-1533. [CrossRef] 